\title{
X-ray Shielding, Mechanical, Physical, and Water Absorption Properties of Wood/PVC Composites Containing Bismuth Oxide
}

\author{
Worawat Poltabtim ${ }^{1} @$, Ekachai Wimolmala ${ }^{2}$, Teerasak Markpin ${ }^{2}{ }^{\oplus}$, Narongrit Sombatsompop ${ }^{2}$, \\ Vichai Rosarpitak ${ }^{3}$ and Kiadtisak Saenboonruang $1,4, *$ (i)
}

1 Department of Applied Radiation and Isotopes, Faculty of Science, Kasetsart University, Bangkok 10900, Thailand; wp.worawat@gmail.com

2 Polymer PROcessing and Flow (P-PROF) Research Group, Division of Materials Technology, School of Energy, Environment and Materials, King Mongkut's University of Technology Thonburi, Bangkok 10140, Thailand; ekachai.wim@kmutt.ac.th (E.W.); teerasak.mar@kmutt.ac.th (T.M.); narongrit.som@kmutt.ac.th (N.S.)

3 V.P. Wood Co., Ltd., Suksawat 41, Banphueng, Phra Pradaeng Samut Prakan 10130, Thailand; cabonyx.sales@gmail.com

4 Specialized Center of Rubber and Polymer Materials in Agriculture and Industry (RPM), Faculty of Science, Kasetsart University, Bangkok 10900, Thailand

* Correspondence: kiadtisak.s@ku.th; Tel.: +662-562-5555 (ext. 646219)

\section{check for} updates

Citation: Poltabtim, W.; Wimolmala, E.; Markpin, T.; Sombatsompop, N.; Rosarpitak, V.; Saenboonruang, K. X-ray Shielding, Mechanical, Physical, and Water Absorption Properties of Wood/PVC Composites Containing Bismuth Oxide. Polymers 2021, 13, 2212. https://doi.org/10.3390/ polym 13132212

Academic Editors: Emmanuel Akpan, Suchart Siengchin and Bernd Wetzel

Received: 14 June 2021

Accepted: 2 July 2021

Published: 4 July 2021

Publisher's Note: MDPI stays neutral with regard to jurisdictional claims in published maps and institutional affiliations.

Copyright: (c) 2021 by the authors. Licensee MDPI, Basel, Switzerland. This article is an open access article distributed under the terms and conditions of the Creative Commons Attribution (CC BY) license (https:// creativecommons.org/licenses/by/ $4.0 /)$.

\begin{abstract}
The potential utilization of wood/polyvinyl chloride (WPVC) composites containing an $\mathrm{X}$-ray protective filler, namely bismuth oxide $\left(\mathrm{Bi}_{2} \mathrm{O}_{3}\right)$ particles, was investigated as novel, safe, and environmentally friendly $X$-ray shielding materials. The wood and $\mathrm{Bi}_{2} \mathrm{O}_{3}$ contents used in this work varied from 20 to 40 parts per hundred parts of PVC by weight (pph) and from 0 to 25, 50, 75, and $100 \mathrm{pph}$, respectively. The study considered X-ray shielding, mechanical, density, water absorption, and morphological properties. The results showed that the overall $X$-ray shielding parameters, namely the linear attenuation coefficient $(\mu)$, mass attenuation coefficient $\left(\mu_{\mathrm{m}}\right)$, and lead equivalent thickness $(\mathrm{Pb}$ eq $)$, of the WPVC composites increased with increasing $\mathrm{Bi}_{2} \mathrm{O}_{3}$ contents but slightly decreased at higher wood contents (40 pph). Furthermore, comparative $\mathrm{Pb}_{\text {eq }}$ values between the wood/PVC composites and similar commercial X-ray shielding boards indicated that the recommended $\mathrm{Bi}_{2} \mathrm{O}_{3}$ contents for the $20 \mathrm{pph}$ (40 ph) wood/PVC composites were 35, 85, and $40 \mathrm{pph}(40,100$, and $45 \mathrm{pph})$ for the attenuation of 60,100 , and $150-\mathrm{kV}$ X-rays, respectively. In addition, the increased $\mathrm{Bi}_{2} \mathrm{O}_{3}$ contents in the WPVC composites enhanced the Izod impact strength, hardness (Shore D), and density, but reduced water absorption. On the other hand, the increased wood contents increased the impact strength, hardness (Shore D), and water absorption but lowered the density of the composites. The overall results suggested that the developed WPVC composites had great potential to be used as effective X-ray shielding materials with $\mathrm{Bi}_{2} \mathrm{O}_{3}$ acting as a suitable $\mathrm{X}$-ray protective filler.
\end{abstract}

Keywords: WPVC; $\mathrm{Bi}_{2} \mathrm{O}_{3}$; X-ray; shielding; radiation; mechanical properties; composites

\section{Introduction}

$\mathrm{X}$-rays are ionizing radiation with energies of $100 \mathrm{eV}-100 \mathrm{keV}$ and frequencies of $10^{16}-10^{20} \mathrm{~Hz}$ and are currently utilized in various applications, including $X$-ray imaging for the diagnosis of brain and lung cancers [1], low-dose X-ray radiotherapy [2], X-ray fluorescence (XRF) and X-ray diffraction (XRD) for material and archeological characterizations [3-5], and X-ray irradiation of economic plants to accelerate breeding and mutations [6]. Despite its great benefit and potential, excessive exposure to X-rays could harmfully affect both the radiation users and the general public, whose symptoms may vary from mild conditions (nausea, vomiting, diarrhea, fever, loss of appetite, skin burn, and hair loss) to severe conditions (cognitive impairment, seizures, electrolyte disturbance, cancers, and death) depending on the X-ray energy, exposure dose and rate, and the organ response to exposure $[7,8]$. Consequently, to reduce and/or prevent risks from 
X-ray exposure, a radiation safety principle called "As Low As Reasonably Achievable" or "ALARA" [9] must be strictly followed in all radiation-related facilities [10]; the principle involves appropriate management of working time and distance, as well as the utilization of sufficient and suitable radiation shielding equipment.

Specifically, in cases where prolonged working time and/or the need to operate close to radiation sources are unavoidable, the use of appropriate and effective radiation shielding equipment is a necessary measure to ensure safety for all users [11,12]. Generally, materials containing high contents of heavy atoms or heavy compounds such as lead $(\mathrm{Pb})$ and $\mathrm{Pb}$ containing compounds $\left(\mathrm{PbO}\right.$ and $\mathrm{Pb}_{2} \mathrm{O}_{3}$ ) are commonly used as parts of $\mathrm{X}$-ray shielding equipment that are both effective and economically accessible due to the relatively high atomic number $(\mathrm{Z}=82)$ and density of $\mathrm{Pb}$, which results in enhanced probabilities of interaction between the incident $\mathrm{X}$-rays and the materials [13]. However, $\mathrm{Pb}$ and $\mathrm{Pb}$-containing compounds are health hazardous as they could severely harm most human and animal organs as well as negatively affect plants and ecosystems [14-16]. To minimize the risks of $\mathrm{Pb}$ exposure, there has been a constant effort to identify $\mathrm{Pb}$-free $\mathrm{X}$-ray shielding materials having comparable or better attenuation abilities than $\mathrm{Pb}$-containing materials, with additional preferred properties such as transparency, flexibility, and self-healable. Examples of recent $\mathrm{Pb}$-free $\mathrm{X}$-ray shielding materials are: $\mathrm{Bi}_{2} \mathrm{O}_{3} /$ polyvinyl chloride (PVC) composites [17], $\mathrm{W} / \mathrm{Bi}_{2} \mathrm{O}_{3} /$ high-functional methyl vinyl silicone rubber (VMQ) composites [18], $\mathrm{W}_{2} \mathrm{O}_{3}$ /ethylene propylene diene monomer (EPDM) composites [19], $\mathrm{Bi}_{2} \mathrm{O}_{3} /$ wood/natural rubber (NR) composites [20], and Bi/high-density polyethylene (HDPE) composites [21], in which $\mathrm{Bi}$ and $\mathrm{W}$ compounds act as alternative $\mathrm{X}$-ray protectively fillers to $\mathrm{Pb}$. It should be noted that the attenuation efficiencies of the mentioned materials vary depending on the filler types, contents, and the manufacturing process of the materials [22].

Among the alternative $\mathrm{X}$-ray protective fillers, $\mathrm{Bi}_{2} \mathrm{O}_{3}$ is promising as a replacement for $\mathrm{Pb}$ and $\mathrm{Pb}$-containing compounds due to the high atomic number of $\mathrm{Bi}$ atoms $(\mathrm{Z}=83)$ and the high density of $\mathrm{Bi}_{2} \mathrm{O}_{3}\left(\rho=8.9 \mathrm{~g} / \mathrm{cm}^{3}\right)$, which result in high interaction probabilities between incident $\mathrm{X}$-rays and shielding materials that are comparable to common $\mathrm{Pb}$-containing materials [23]. For example, EPDM composites containing 500 parts per hundred parts of rubber by weight $(\mathrm{phr})$ of $\mathrm{Bi}_{2} \mathrm{O}_{3}$ had a mean ( \pm standard deviation) linear attenuation coefficient $(\mu)$ of $24.3 \pm 2.2 \mathrm{~m}^{-1}$ at a gamma energy of $1.25 \mathrm{MeV}$ [19], which was comparable with NR composites containing the same Pb content $\left(\mu=26.0 \mathrm{~m}^{-1}\right)$ [24]. This comparison implied a promising X-ray attenuation capability of $\mathrm{Bi}_{2} \mathrm{O}_{3}$ that could potentially replace $\mathrm{Pb}$ and $\mathrm{Pb}$-containing compounds as an effective protective filler. Furthermore, $\mathrm{Bi}_{2} \mathrm{O}_{3}$ is considerably safer for users and the environment than $\mathrm{Pb}$ as evidenced by the wide application of $\mathrm{Bi}_{2} \mathrm{O}_{3}$ in medical and industrial applications such as being an active ingredient of Pepto-Bismal (an over-the-counter medicine for the treatment of stomach disorders) and as green Lewis acid catalysts in organic synthesis, respectively [25].

In addition to $X$-ray protective fillers, selection of the main matrix also plays an important role in defining the useability of the developed materials in actual applications, because other important properties such as mechanical strength, water absorption, and flexibility, of the composites largely depend on the properties of the main matrix [26,27]. In particular for X-ray shielding materials used as movable panels, radio-diagnostic walls, and transportation casks, wood/plastic composites (WPC), especially wood/PVC (WPVC) composites, are most interesting for such purposes due to their light weight, low water absorption, termite resistance, humidity resistance, environmental erosion resistance, dimensional stability, and low maintenance requirements, resulting in their broad potential for utilization [28-31]. Despite their attractive properties, the use of WPC as radiation shielding material, especially for X-ray attenuation, is presently limited as most of available products and reports have been primarily aimed at preventing the interference of low-energy electromagnetic (EM) waves (radio and microwaves) on electrical devices. Examples of WPC used as electromagnetic interference (EMI) shielding materials are graphene/WPC and Ni/wood/PVC composites, which were used as EMI shields for EM waves with frequencies of $60 \mathrm{MHz}-1.5 \mathrm{GHz}$ and $8.2 \mathrm{GHz}-12.4 \mathrm{GHz}$, respectively [32,33]. 
As aforementioned, the current work aimed to expand the limited information/data on WPC, especially on WPVC composites, in X-ray shielding applications by determining the $\mathrm{X}$-ray attenuation, mechanical, morphological, density, and water absorption properties of WPVC composites containing $\mathrm{Bi}_{2} \mathrm{O}_{3}$ particles. The contents of wood particles were varied from 20 to 40 parts per hundred parts (pph) of $\mathrm{PVC}$ by weight and the $\mathrm{Bi}_{2} \mathrm{O}_{3}$ contents were varied from 0 to, 25, 50, 75, and $100 \mathrm{pph}$. The X-rays used for the measurement of shielding properties were generated from an $\mathrm{X}$-ray tube with supplied voltages of 60, 100, and $150 \mathrm{kV}$, and the following $\mathrm{X}$-ray shielding properties were determined and reported: $\mu$, the mass attenuation coefficient $\left(\mu_{\mathrm{m}}\right)$, and the $\mathrm{Pb}$ equivalent thickness $(\mathrm{Pb}$ eq $)$. In addition, recommended $\mathrm{Bi}_{2} \mathrm{O}_{3}$ contents for each X-ray energy were determined. The outcomes of this work should not only present novel, effective, and safe X-ray shielding materials from $\mathrm{Bi}_{2} \mathrm{O}_{3} /$ WPVC composites but also broaden the data availability of WPVC-based materials for future development as improved radiation shielding materials.

\section{Experimental}

\subsection{Materials and Chemicals}

Suspension PVC powder (trade name SIAMVIC-258RB) with a K value of 58 was used as the main matrix for this work. Other chemicals, with their functions, contents, and suppliers, for the production of WPVC composites are given in Table 1. Optical and micrograph images of wood particles and $\mathrm{Bi}_{2} \mathrm{O}_{3}$ taken using a scanning electron microscope are shown in Figure 1. It should be noted that their mean ( \pm standard deviation) particle sizes were $0.5 \pm 0.1 \mathrm{~mm}$ and $27.4 \pm 8.2 \mu \mathrm{m}$, respectively, determined using their respective micrograph images in the Image J software (version 1.50i).

Table 1. Material formulations of WPVC composites and chemical names, contents, functions, and suppliers.

\begin{tabular}{cccc}
\hline Chemicals & Content (pph) & Function & Supplier \\
\hline $\begin{array}{c}\text { Suspension PVC grade } \\
\text { SIAMVIC-258RB }\end{array}$ & 100 & Matrix & Vinythai Public Co., Ltd. (Rayong, Thailand) \\
Emulsion PVC grade & & & \\
SIAMVIC-167GZ & 4.0 & PVC additive & V.P. Wood Co., Ltd. (Samut Prakan, Thailand) \\
PF 608A, Pb-Ba based organic & 3.6 & Thermal stabilizer & V.P. Wood Co., Ltd. (Samut Prakan, Thailand) \\
PF 601 & 1.5 & Thermal stabilizer & V.P. Wood Co., Ltd. (Samut Prakan, Thailand) \\
Finalux G-741 & 0.6 & External lubricant & V.P. Wood Co., Ltd. (Samut Prakan, Thailand) \\
Calcium stearate & 0.6 & Internal lubricant & V.P. Wood Co., Ltd. (Samut Prakan, Thailand) \\
Calcium carbonate, Omyacarb-2T & 12.0 & Filler & V.P. Wood Co., Ltd. (Samut Prakan, Thailand) \\
Modified Chlorinated Polyethylene & 7.7 & Impact modifier & V.P. Wood Co., Ltd. (Samut Prakan, Thailand) \\
(CPE) & 6.0 & Processing aid & V.P. Wood Co., Ltd. (Samut Prakan, Thailand) \\
PA-20 & 20 and 40 & Filler & V.P. Wood Co., Ltd. (Samut Prakan, Thailand) \\
$\begin{array}{c}\text { Para rubber wood particles } \\
\text { N-2-(Aminoethyl)-3- }\end{array}$ & $1 \mathrm{wt} \%$ of wood & Silane coupling agent & Shin-Etsu Chemical Co., Ltd., (Tokyo, Japan) \\
aminopropyltrimethoxysilane & & & Shanghai Ruizheng Chemical Technology Co., \\
(KBM603) & $0,25,50,75$, and 100 & X-ray protective agent & \\
Bismuth oxide; Bi ${ }_{2} \mathrm{O}_{3}$ & & &
\end{tabular}

\subsection{Preparation of WPVC Composites}

The wood particles were chemically surface-treated with a silane coupling agent (KBM603) solution using a high-speed mixer at $1000 \mathrm{rpm}$ for $5 \mathrm{~min}$ and dried in a hot-air oven (GT-7017-L, Gotech Testing Machine, Taichung City, Taiwan) at $80^{\circ} \mathrm{C}$ for $72 \mathrm{~h}$ until constant weight was achieved. It should be noted that the treatment of the wood particles followed procedures optimized by our previous works [34]. Then, the surface-treated wood particles were mixed with the suspension PVC and other chemicals (Table 1) using a highspeed mixer at $1000 \mathrm{rpm}$ for $5 \mathrm{~min}$. The mixtures were then melt-blended using a twin-screw extruder (CTW 100 QC, HAAKETM Rheomex, Kahlsruhe, Germany) with a screw speed of $40 \mathrm{rpm}$ and temperature settings of $140,150,160$, and $160^{\circ} \mathrm{C}$ for the feed zone, plastification 
zone, mixing zone, and die zone, respectively. The extrudate was then pelletized into granules and dried in a hot-air oven at $80^{\circ} \mathrm{C}$ overnight to completely remove moisture. The dried granules were then molded into specimens using hot compression molding (LP-20M; Labtech Engineering Co., Ltd., Bangkok, Thailand) at $170{ }^{\circ} \mathrm{C}$ and pressure of $150 \mathrm{~kg} / \mathrm{cm}^{2}$ for $8 \mathrm{~min}$. It should be noted that the molds used in this work were $15 \mathrm{~cm} \times 15 \mathrm{~cm}$ with two different thicknesses ( $3 \mathrm{~mm}$ and $10 \mathrm{~mm}$ ).

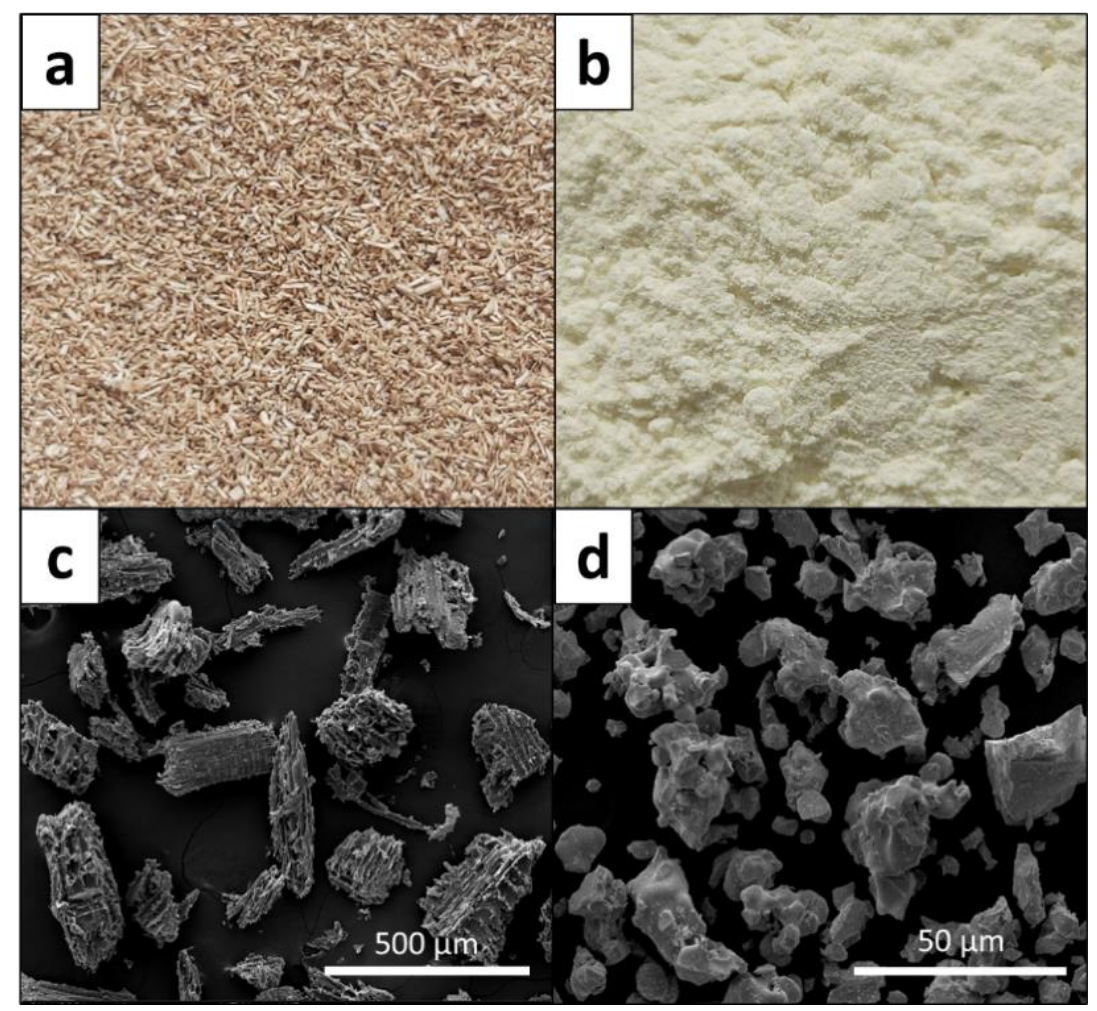

Figure 1. Optical images of (a) wood particles and (b) $\mathrm{Bi}_{2} \mathrm{O}_{3}$ particles, and micrograph images of (c) wood particles and (d) $\mathrm{Bi}_{2} \mathrm{O}_{3}$ particles.

\subsection{Characterization}

\subsubsection{X-ray Shielding Measurement}

The X-ray shielding properties of the WPVC composites were characterized by determining the values of the $X$-ray transmission ratio $\left(I / I_{0}\right)$, the linear attenuation coefficient $(\mu)$, the mass attenuation coefficient $\left(\mu_{\mathrm{m}}\right)$, and the lead $(\mathrm{Pb})$ equivalent thickness $\left(\mathrm{Pb}_{\mathrm{eq}}\right)$ [12]. The tests were performed at the Secondary Standard Dosimetry Laboratory (SSDL), the Office of Atoms for Peace (OAP), Bangkok, Thailand, using the experimental setup shown in Figure 2.

To perform the $\mathrm{X}$-ray shielding measurement, $\mathrm{X}$-rays, generated using an $\mathrm{X}$-ray tube with supplied voltages of 60,100 , and $150 \mathrm{kV}$, and collimated using a $1 \mathrm{~mm} \mathrm{~Pb}$ pinhole, were directed at the center of $10 \mathrm{~mm}$-thick WPVC samples. The transmitted X-rays were then detected and counted using a free air ionization chamber (Korea Research Institute of Standards and Science, KRISS; Daejeon, Korea), which was installed on the calibration bench in the setup. It should be noted that the detector was powered by a high voltage power supply (Keithley 247, Cleveland, OH, USA) and connected to an electrometer (Keithley 6517B, Cleveland, OH, USA) to complete the detection system. The X-ray source used in this work was controlled by X-ray systems (YXLON MGC41, Hudson, NY, USA) and their energies were selected based on the standard method recommended by ISO4037-1:2019. 


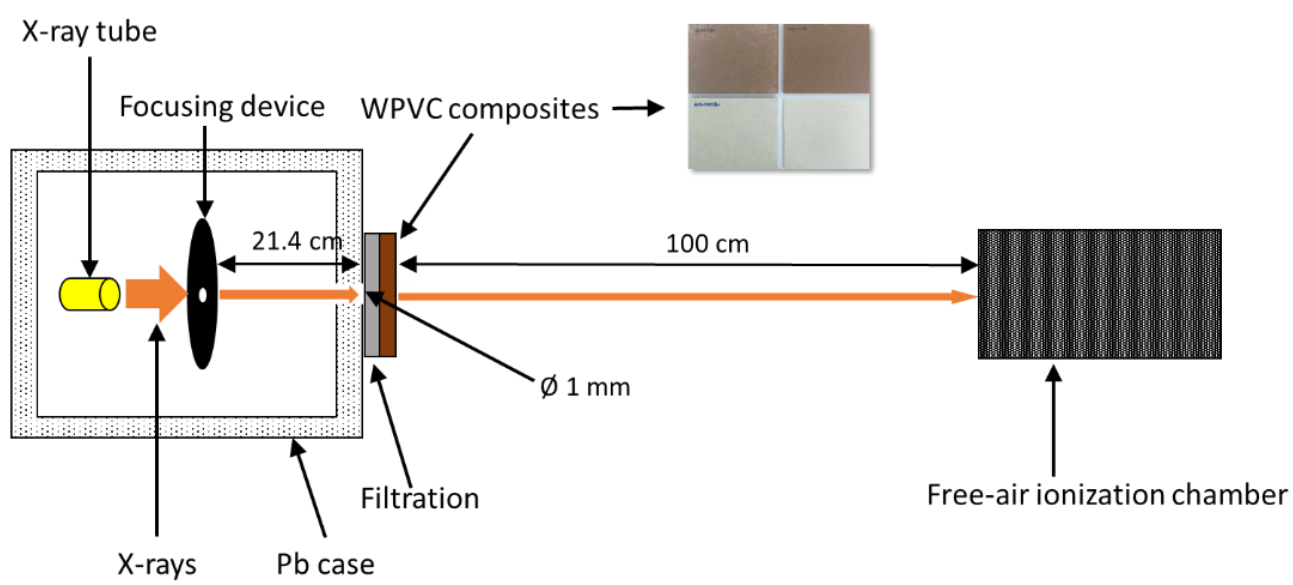

Figure 2. Experimental setup for X-ray shielding measurement.

To determine $\mathrm{I} / \mathrm{I}_{0}, \mu, \mu_{\mathrm{m}}$, and $\mathrm{Pb}_{\text {eq }}$, three independent 5 min tests were performed and their values were calculated using Equations (1)-(3):

$$
\begin{gathered}
\mathrm{I}=\mathrm{I}_{0} \mathrm{e}^{-\mu \mathrm{x}} \\
\mu_{\mathrm{m}}=\mu \rho \\
\mu_{\mathrm{Pb}} \times \mathrm{Pb}_{\mathrm{eq}}=\mu_{\text {WPVC }} \times \mathrm{x}
\end{gathered}
$$

where $\mathrm{I}, \mathrm{I}_{0}, \mathrm{x}, \rho, \mu_{\mathrm{Pb}}$, and $\mu_{\mathrm{WPVC}}$ are the intensity of transmitted X-rays, the intensity of the incident X-rays, the thickness of the WPVC samples, the density of the WPVC samples, the linear attenuation coefficient of $\mathrm{Pb}$, and the linear attenuation coefficient of the WPVC samples, respectively. For comparative purposes, a pure $\mathrm{Pb}$ sheet was also tested using the same testing procedure and setup, and its $\mathrm{I} / \mathrm{I}_{0}$ and $\mu_{\mathrm{Pb}}$ were calculated and reported.

\subsubsection{Mechanical Properties}

The flexural strength of the WPVC composites was investigated using a universal testing machine (The Starrett FMS5000; Lynchburg, VA, USA), following the ASTM D790-10 standard testing. The Izod impact strength of the WPVC composites was measured according to ASTM D256-10, using a pendulum impact testing machine (United Test JB-300B; Beijing United Test Co., Ltd., Beijing, China). For hardness (Shore D) measurement, all samples were tested according to ASTM D2240-05 standard testing using a hardness durometer (Shore D) (Teclock GS-720N, Nagano, Japan). It should be noted that all mechanical measurements were conducted with at least three specimens for each formulation.

\subsubsection{Morphology and Density Measurement}

The morphology and dispersion of the $\mathrm{Bi}_{2} \mathrm{O}_{3}$ and wood particles in the WPVC composites were determined using scanning electron microscopy (SEM) and energy dispersive X-ray spectroscopy (EDX) (Quanta 450 FEI: JSM-6610LV, Eindhoven, The Netherlands) at a 10-kV accelerating voltage. Prior to the SEM-EDX images being taken, all specimens were coated with gold using a sputter coater (Quorum SC7620: Mini Sputter Coater/Glow Discharge System, Laughton, UK) at a power voltage of $10 \mathrm{kV}$ and a current of $10 \mathrm{~mA}$ for $120 \mathrm{~s}$.

The density $(\rho)$ of each sample was determined by finding the ratio of the mass $(\mathrm{m})$ to the volume $(\mathrm{V})$ of the specimen [11] and the results are shown in Table 2, which indicates that the densities tended to increase with increasing $\mathrm{Bi}_{2} \mathrm{O}_{3}$ contents but slightly decreased with increasing wood contents. This could have been due to the much higher density of $\mathrm{Bi}_{2} \mathrm{O}_{3}\left(\rho_{\mathrm{Bi} 2 \mathrm{O} 3}=8.9 \mathrm{~g} / \mathrm{cm}^{3}\right)[12,19,23]$ compared to PVC $\left(\rho_{\mathrm{PVC}}=1.43 \mathrm{~g} / \mathrm{cm}^{3}\right)[35]$ that resulted in the higher overall densities of the WPVC composites after the addition of $\mathrm{Bi}_{2} \mathrm{O}_{3}$ into the composites. In contrast to $\mathrm{Bi}_{2} \mathrm{O}_{3}$, the addition of wood particles slightly reduced 
the overall densities of the composites as the wood particles had much lower densities than $\mathrm{Bi}_{2} \mathrm{O}_{3}$ and PVC $\left(\rho_{\text {wood }}=0.48-0.65 \mathrm{~g} / \mathrm{cm}^{3}\right)$ [36], resulting in an approximately $2 \%$ decrease in the densities of the WPVC composites containing $40 \mathrm{pph}$ wood particles compared to those with 20 pph wood particles.

Table 2. Densities of WPVC composites containing varying contents of $\mathrm{Bi}_{2} \mathrm{O}_{3}$ and wood particles (0-100 pph in $25 \mathrm{pph}$ increments and 20 to $40 \mathrm{pph}$, respectively), where results are shown as mean \pm standard deviation of the mean.

\begin{tabular}{ccc}
\hline \multirow{2}{*}{$\mathbf{B i}_{2} \mathbf{O}_{3}$ Content (pph) } & \multicolumn{2}{c}{ Density $\left(\mathrm{g} / \mathrm{cm}^{\mathbf{3}}\right)$} \\
\cline { 2 - 3 } & $\mathbf{2 0} \mathbf{~ p p h ~ W o o d}$ & $\mathbf{4 0} \mathbf{p p h}$ Wood \\
\hline 0 & $1.46 \pm 0.01$ & $1.43 \pm 0.02$ \\
25 & $1.63 \pm 0.02$ & $1.60 \pm 0.02$ \\
50 & $1.79 \pm 0.03$ & $1.78 \pm 0.01$ \\
75 & $1.97 \pm 0.01$ & $1.90 \pm 0.03$ \\
100 & $2.09 \pm 0.04$ & $2.04 \pm 0.01$ \\
\hline
\end{tabular}

\subsubsection{Water Absorption Measurement}

The measurement of water absorption for all WPVC composites was performed following ASTM D570-98 (2018) standard testing, with at least three specimens for each formulation tested. The WPVC specimens were dried in a hot-air oven (GT-7017-L, Gotech Testing Machine, Taiwan) at $50^{\circ} \mathrm{C}$ for $24 \mathrm{~h}$ to achieve a constant weight and then immersed in a deionized water bath for $24 \mathrm{~h}$. The specimens were taken out of the water, wiped with tissue paper to remove surface water, and immediately reweighed on a balance with precision of $0.0001 \mathrm{~g}$. The percentage of water absorption was then calculated by finding the ratio of the weight difference between the sample submerged in water $\left(W_{s}\right)$ and the dried sample $\left(W_{d}\right)$ to the weight of the dried sample $\left(W_{d}\right)$ as shown in Equation (4):

$$
\text { Water absorption }(\%)=\frac{W_{s}-W_{d}}{W_{d}} \times 100
$$

\section{Results and Discussion}

\subsection{Mechanical Properties}

Mechanical properties, namely the flexural strength, the Izod impact strength, and the hardness (Shore D), of the WPVC composites containing varying contents of $\mathrm{Bi}_{2} \mathrm{O}_{3}$ are shown in Figure 3. The results indicated that values of flexural strength for all samples were not statistically different (the values fluctuated within their standard deviations), with the values being in the range 40.92-45.49 MPa. This behavior was observed due to the wood particles, for which their surfaces were chemically treated using a silane coupling agent, exhibiting improved compatibility with the PVC matrix, as well as the added $\mathrm{Bi}_{2} \mathrm{O}_{3}$ being uniformly dispersed throughout the matrix by the high shear stress of a twin-screw extruder. In addition, the results suggested that the values of the Izod impact strength and hardness (Shore $\mathrm{D}$ ) were enhanced with the addition of $\mathrm{Bi}_{2} \mathrm{O}_{3}$, except for the WPVC composites containing $100 \mathrm{pph} \mathrm{Bi}_{2} \mathrm{O}_{3}$ and $40 \mathrm{pph}$ wood particles that had noticeably lower Izod impact strength than those with 75 pph $\mathrm{Bi}_{2} \mathrm{O}_{3}$ and 40 pph wood particles (approximately $30 \%$ decrease). Similar to $\mathrm{Bi}_{2} \mathrm{O}_{3}$, the samples having a higher wood content ( $40 \mathrm{pph}$ ) generally had higher overall mechanical strength at the same $\mathrm{Bi}_{2} \mathrm{O}_{3}$ content than those with $20 \mathrm{pph}$ wood particles, implying the role of wood particles in the WPVC composites as a reinforcing filler. 

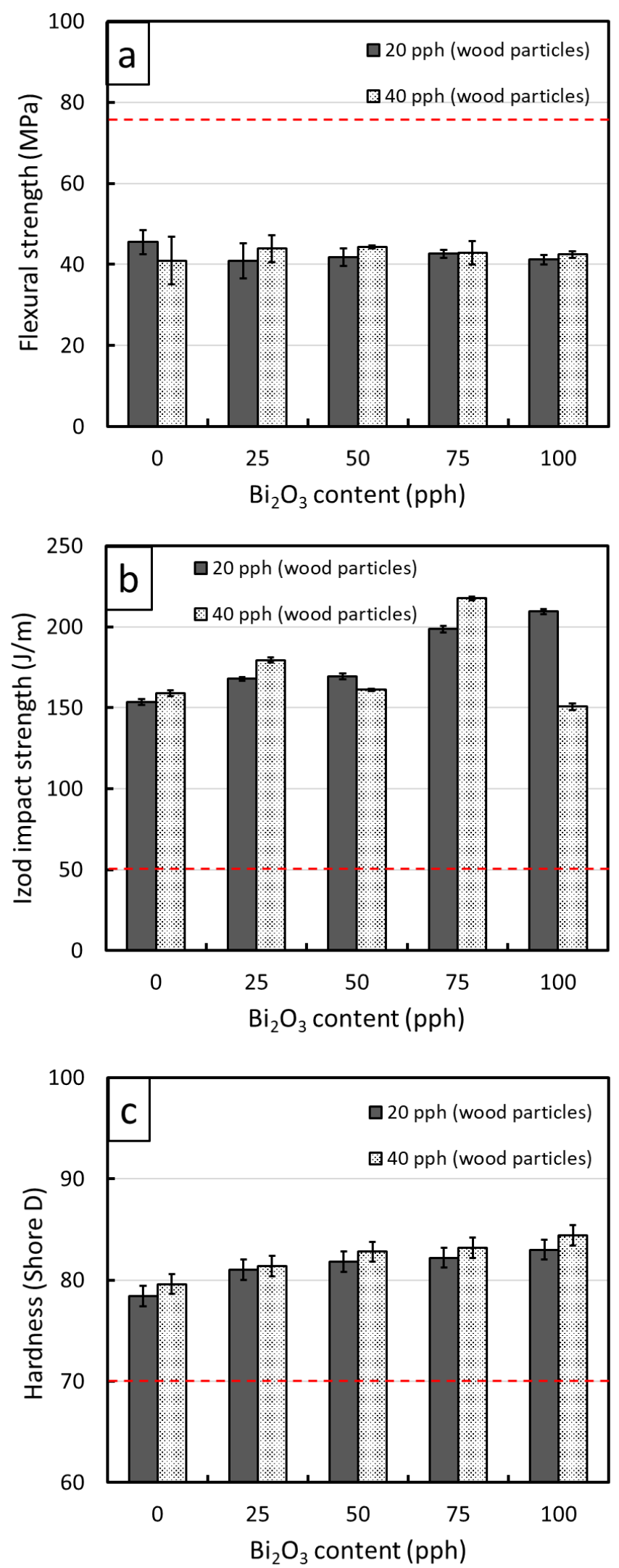

Figure 3. (a) Flexural strength, (b) Izod impact strength, and (c) hardness (Shore D) of WPVC composites containing 0-100 pph of $\mathrm{Bi}_{2} \mathrm{O}_{3}$ and 20-40 pph of wood particles, where error bars $= \pm$ standard deviation. The red-dashed lines represent flexural strength, Izod impact strength, and hardness (Shore D) of a neat PVC obtained from [37-39]. 
The increases in the Izod impact strength with the addition of $\mathrm{Bi}_{2} \mathrm{O}_{3}$ and wood particles, which was as high as $217.5 \pm 1.3 \mathrm{~J} / \mathrm{m}$ in the sample with $75 \mathrm{pph} \mathrm{Bi}_{2} \mathrm{O}_{3}$ and $40 \mathrm{pph}$ wood particles, could have been due to both fillers in the matrix limiting chain segmental motions and consequently reducing the flexibility of the matrix reins that required higher energy to fracture the WPVC composites $[40,41]$. However, for the composites with very high filler contents, such as with $100 \mathrm{pph} \mathrm{Bi}_{2} \mathrm{O}_{3}$ and $40 \mathrm{pph}$ wood particles, the Izod impact strength was considerably lower than those having less filler due to increases in the agglomeration of fillers in the PVC matrix that resulted in increased numbers of defects and voids. To illustrate the effects of a high filler content on the morphology of a composite, SEM images showing filler distribution as well as particle agglomeration in different composites are shown in Figure 4, which indicates that the composites with 100 pph $\mathrm{Bi}_{2} \mathrm{O}_{3}$ (Figure $4 \mathrm{e}, \mathrm{f}$ ) clearly had more voids in the matrix than the neat WPVC composites (Figure $4 \mathrm{a}, \mathrm{b}$ ) and those containing $50 \mathrm{pph}$ of $\mathrm{Bi}_{2} \mathrm{O}_{3}$ (Figure $4 \mathrm{c}, \mathrm{d}$ ), resulting in a substantially reduced Izod impact strength. It was notable that the observed behaviors were in agreement with previous reports of $\mathrm{SiO}_{2}$ /epoxy and graphene oxide/epoxy composites for which the impact strength decreased at high filler contents caused by the agglomeration of the fillers [40,41]. In addition to the flexural and Izod impact strengths, Figure 3c suggested that the hardness (Shore D) of the WPVC composites increased with increasing $\mathrm{Bi}_{2} \mathrm{O}_{3}$ and wood contents. This behavior was observed due to the high rigidity of the $\mathrm{Bi}_{2} \mathrm{O}_{3}$ and wood particles that enhanced the overall rigidity and, subsequently, surface hardness of the WPVC composites [19,42].

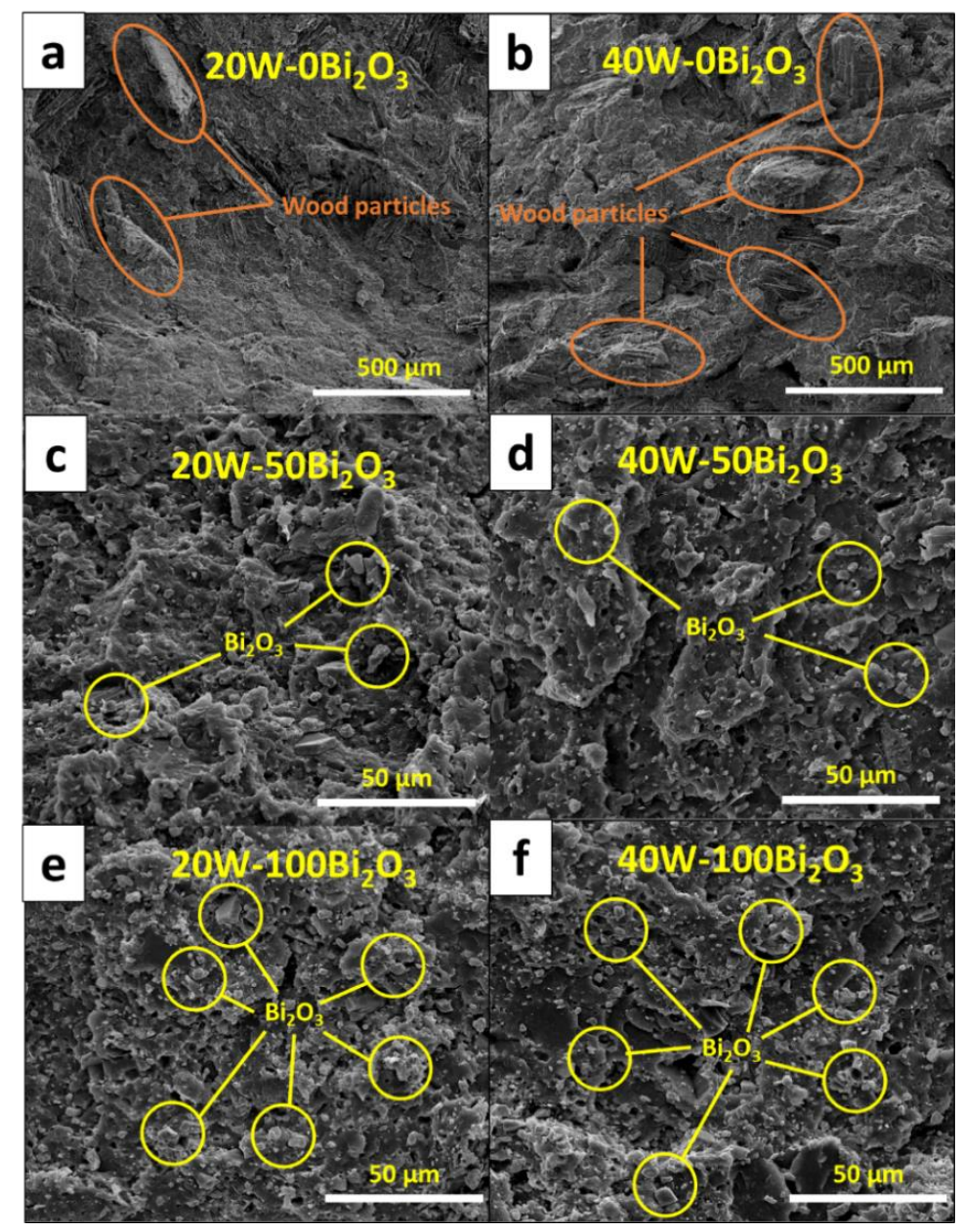

Figure 4. SEM images of WPVC composites containing (a) 20 pph wood particles, (b) 40 pph wood particles, (c) 50 pph $\mathrm{Bi}_{2} \mathrm{O}_{3}$ and 20 pph wood particles, (d) 50 pph $\mathrm{Bi}_{2} \mathrm{O}_{3}$ and 40 pph wood particles, (e) 100 pph $\mathrm{Bi}_{2} \mathrm{O}_{3}$ and 20 pph wood particles, and (f) 100 pph $\mathrm{Bi}_{2} \mathrm{O}_{3}$ and 40 pph wood particles. 
Figure 3 also shows mechanical properties of a neat PVC (dashed lines), indicating that the values of flexural strength of WPVC composites were lower than the neat PVC, which could be due to incompatibility between the PVC matrix and the wood particles as well as differences in shrinkage of the matrix and wood particles during cooling, which generated defects and voids within the composites [37]. On the other hand, the Izod impact strength and hardness (Shore D) of the WPVC composites were noticeably higher than the neat PVC, mainly due to the reduced chain segmental motions caused by the added fillers and the high rigidity of the fillers, respectively.

\subsection{Water Absorption}

The results for the determination of water absorption in the WPVC composites containing varying contents of $\mathrm{Bi}_{2} \mathrm{O}_{3}$ and wood particles are shown in Figure 5, which revealed that the percentage of water absorption decreased (increased) with increasing $\mathrm{Bi}_{2} \mathrm{O}_{3}$ (wood) contents. For example, samples containing $40 \mathrm{pph}$ wood particles had approximately two times higher water absorption than those containing $20 \mathrm{pph}$ wood particles at the same $\mathrm{Bi}_{2} \mathrm{O}_{3}$ content, due to the increased numbers of hydroxyl groups in the wood fiber structure that enhanced the overall hydrophilicity and, subsequently, the water absorption of the former composites [31]. In contrast, increases in the $\mathrm{Bi}_{2} \mathrm{O}_{3}$ contents resulted in lower water absorption of the WPVC composites. This could have been due to the dilution effects of $\mathrm{Bi}_{2} \mathrm{O}_{3}$, which had lower hydrophilicity than the wood particles as seen by greater water contact angle of $\sim 107^{\circ}$ in $\mathrm{Bi}_{2} \mathrm{O}_{3}$ [43] than those of $\sim 65^{\circ}$ in wood particles [44], which resulted in a lower weight fraction of wood particles in the composites and, consequently, reduced the overall hydrophilicity and water absorption of the composites [42].

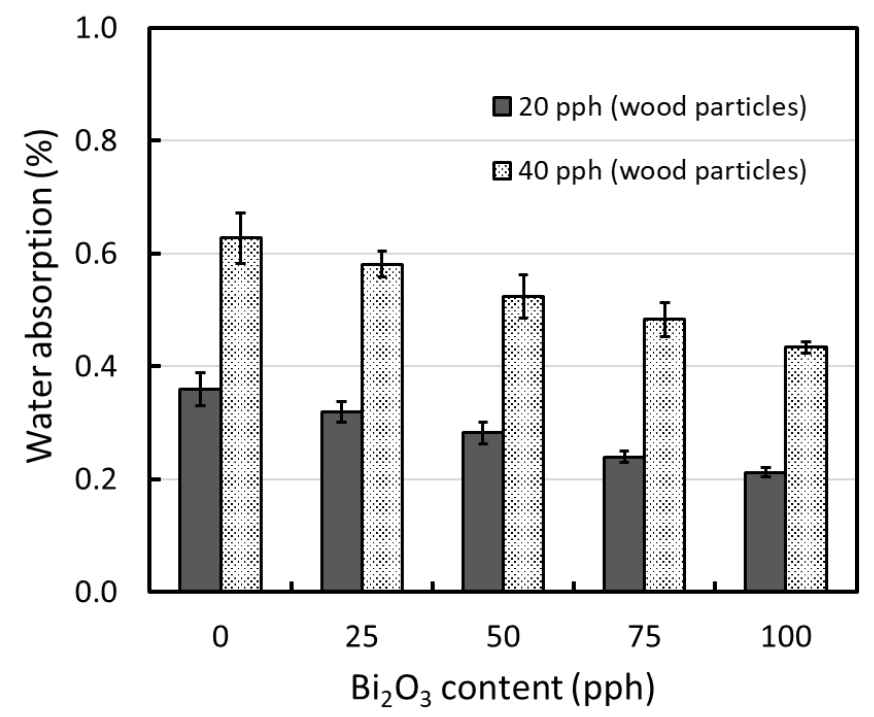

Figure 5. Water absorption of WPVC composites containing 0-100 pph of $\mathrm{Bi}_{2} \mathrm{O}_{3}$ and 20-40 pph of wood particles, where error bars $= \pm$ standard deviation.

\subsection{X-ray Shielding Properties}

Table 3 shows the values of $\mu$ and $\mu_{\mathrm{m}}$ (representing the fraction of attenuated incident $\mathrm{X}$-rays in a monoenergetic beam per unit thickness and unit mass, respectively) in the WPVC composites containing 0-100 pph of $\mathrm{Bi}_{2} \mathrm{O}_{3}$ and $20-40$ pph of wood particles. The results indicated that increases in the $\mathrm{Bi}_{2} \mathrm{O}_{3}$ content led to the overall enhancement of $\mathrm{X}$-ray shielding properties as seen by the notable increases in the values of $\mu$ and $\mu_{\mathrm{m}}$ at higher $\mathrm{Bi}_{2} \mathrm{O}_{3}$ contents. The most pronounced increases in $\mu$ and $\mu_{\mathrm{m}}$ were observed when $\mathrm{Bi}_{2} \mathrm{O}_{3}$ was initially added to neat WPVC composites (from 0 to $25 \mathrm{pph}$ ), resulting in approximately a two-times improvement in the $\mu$ and $\mu_{\mathrm{m}}$ values. The positive dependency of the $\mathrm{X}$-ray shielding abilities on the $\mathrm{Bi}_{2} \mathrm{O}_{3}$ contents was mainly due to the effective role of $\mathrm{Bi}_{2} \mathrm{O}_{3}$ in the enhancement of $\mathrm{X}$-ray attenuation, with $\mathrm{Bi}_{2} \mathrm{O}_{3}$ acting as an $\mathrm{X}$-ray attenuator that increased 
the interaction probabilities between the incident $X$-rays and the materials [22,24]. To show the distribution of Bi elements in the WPVC composites, especially for those having high $\mathrm{Bi}_{2} \mathrm{O}_{3}$ contents, SEM-EDX images of all samples containing $\mathrm{Bi}_{2} \mathrm{O}_{3}$ are shown in Figure 6, which revealed that there were clearly more $\mathrm{Bi}$ atoms (shown as red areas) in the samples having higher $\mathrm{Bi}_{2} \mathrm{O}_{3}$ contents, especially in Figure $6 \mathrm{~g}, \mathrm{~h}$. Thus, there was a higher X-ray shielding capability because there were more available Bi atoms to interact with $\mathrm{X}$-rays.

Table 3. X-ray shielding properties, including linear attenuation coefficients $(\mu)$ and mass attenuation coefficient $\left(\mu_{\mathrm{m}}\right)$ of WPVC composites containing 0-100 pph of $\mathrm{Bi}_{2} \mathrm{O}_{3}$ and 20-40 pph of wood particles, Pb sheet, and a neat PVC, determined for X-ray levels of 60,100, and 150-kV. Results are shown as mean \pm standard deviation.

\begin{tabular}{|c|c|c|c|c|c|c|c|}
\hline \multirow{2}{*}{ Wood Content (pph) } & \multirow{2}{*}{$\mathrm{Bi}_{2} \mathrm{O}_{3}$ Content (pph) } & \multicolumn{3}{|c|}{$\mu\left(\mathrm{cm}^{-1}\right)$} & \multicolumn{3}{|c|}{$\mu_{\mathrm{m}}\left(\mathrm{cm}^{2} / \mathrm{g}\right)$} \\
\hline & & $60 \mathrm{kV}$ & $100 \mathrm{kV}$ & $150 \mathrm{kV}$ & $60 \mathrm{kV}$ & $100 \mathrm{kV}$ & $150 \mathrm{kV}$ \\
\hline 0 & 0 & 1.02 & 0.36 & 0.25 & 0.73 & 0.26 & 0.18 \\
\hline \multirow{5}{*}{20} & 0 & $0.84 \pm 0.01$ & $0.35 \pm 0.01$ & $0.29 \pm 0.01$ & $0.57 \pm 0.01$ & $0.24 \pm 0.01$ & $0.20 \pm 0.01$ \\
\hline & 25 & $2.48 \pm 0.01$ & $0.94 \pm 0.01$ & $0.95 \pm 0.01$ & $1.53 \pm 0.01$ & $0.58 \pm 0.01$ & $0.58 \pm 0.01$ \\
\hline & 50 & $3.74 \pm 0.01$ & $1.39 \pm 0.01$ & $1.51 \pm 0.01$ & $2.08 \pm 0.01$ & $0.77 \pm 0.01$ & $0.84 \pm 0.01$ \\
\hline & 75 & $4.48 \pm 0.04$ & $1.75 \pm 0.03$ & $2.03 \pm 0.01$ & $2.27 \pm 0.02$ & $0.89 \pm 0.02$ & $1.03 \pm 0.01$ \\
\hline & 100 & $5.04 \pm 0.07$ & $2.11 \pm 0.01$ & $2.51 \pm 0.01$ & $2.41 \pm 0.03$ & $1.01 \pm 0.01$ & $1.20 \pm 0.01$ \\
\hline \multirow{5}{*}{40} & 0 & $0.76 \pm 0.01$ & $0.34 \pm 0.01$ & $0.27 \pm 0.01$ & $0.53 \pm 0.01$ & $0.23 \pm 0.01$ & $0.19 \pm 0.01$ \\
\hline & 25 & $2.23 \pm 0.01$ & $0.85 \pm 0.01$ & $0.85 \pm 0.01$ & $1.40 \pm 0.01$ & $0.53 \pm 0.01$ & $0.53 \pm 0.01$ \\
\hline & 50 & $3.32 \pm 0.01$ & $1.28 \pm 0.01$ & $1.34 \pm 0.01$ & $1.86 \pm 0.01$ & $0.72 \pm 0.01$ & $0.75 \pm 0.01$ \\
\hline & 75 & $4.23 \pm 0.06$ & $1.61 \pm 0.02$ & $1.86 \pm 0.01$ & $2.23 \pm 0.01$ & $0.85 \pm 0.01$ & $0.98 \pm 0.01$ \\
\hline & 100 & $4.63 \pm 0.04$ & $1.86 \pm 0.02$ & $2.29 \pm 0.01$ & $2.27 \pm 0.02$ & $0.91 \pm 0.01$ & $1.13 \pm 0.01$ \\
\hline \multicolumn{2}{|c|}{$\mathrm{Pb}$ sheet } & $63.06 \pm 0.05$ & $25.99 \pm 0.13$ & $29.59 \pm 0.03$ & $5.56 \pm 0.01$ & $2.25 \pm 0.01$ & $2.61 \pm 0.01$ \\
\hline
\end{tabular}

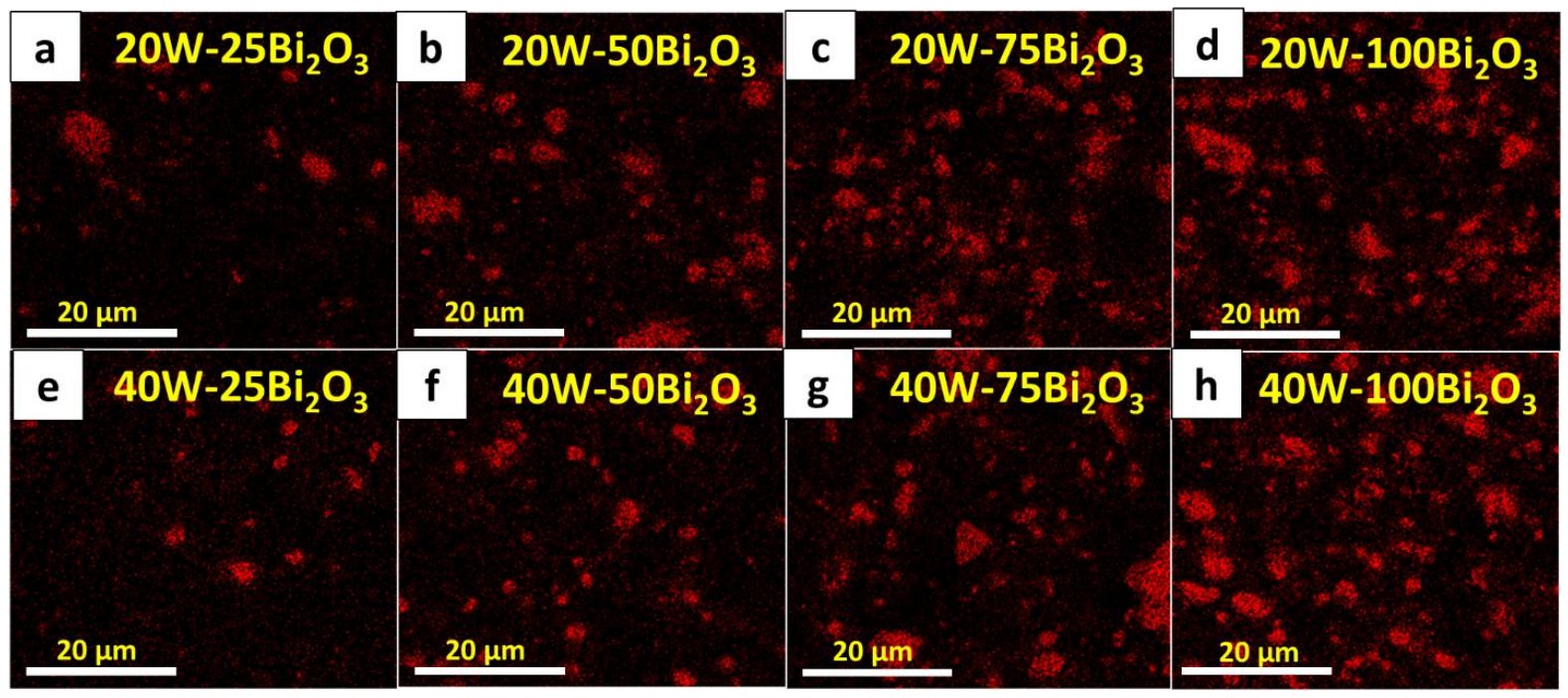

Figure 6. SEM-EDX images showing dispersion of Bi element in WPVC composites with (a) 20 pph wood particles and 25 pph $\mathrm{Bi}_{2} \mathrm{O}_{3}$, (b) 20 pph wood particles and 50 pph $\mathrm{Bi}_{2} \mathrm{O}_{3}$, (c) 20 pph wood particles and 75 pph $\mathrm{Bi}_{2} \mathrm{O}_{3}$, (d) 20 pph wood particles and 100 pph $\mathrm{Bi}_{2} \mathrm{O}_{3}$, (e) 40 pph wood particles and 25 pph $\mathrm{Bi}_{2} \mathrm{O}_{3}$, (f) 40 pph wood particles and 50 pph $\mathrm{Bi}_{2} \mathrm{O}_{3}$, (g) 40 pph wood particles and 75 pph $\mathrm{Bi}_{2} \mathrm{O}_{3}$, and (h) $40 \mathrm{pph}$ wood particles and $100 \mathrm{pph} \mathrm{Bi}_{2} \mathrm{O}_{3}$. Red areas represent presence of $\mathrm{Bi}$ in composites.

On the other hand, Table 3 showed that increasing the wood content from $20 \mathrm{pph}$ to $40 \mathrm{pph}$ resulted in slightly lower values of $\mu$ and $\mu_{\mathrm{m}}$, although the reduced values were less than $10 \%$ (determined for the same $\mathrm{Bi}_{2} \mathrm{O}_{3}$ content). This lower $\mathrm{X}$-ray shielding property for samples with more wood particles added to the composite was due to the much lower X-ray interaction probability for the wood particles (mostly comprised of $\mathrm{C}, \mathrm{H}$, and $\mathrm{O}$ ) compared to $\mathrm{Bi}_{2} \mathrm{O}_{3}\left(\mu_{\mathrm{m}-\text { wood }}=0.162 \mathrm{~cm}^{2} / \mathrm{g}\right.$ and $\mu_{\mathrm{m}-\mathrm{Bi} 2 \mathrm{O} 3}=5.162 \mathrm{~cm}^{2} / \mathrm{g}$ for $100 \mathrm{keV}$ X-rays [45]), resulting in suppressed effects of $\mathrm{Bi}_{2} \mathrm{O}_{3}$ in X-ray attenuation and thus, 
less X-ray shielding capability for those samples containing $40 \mathrm{pph}$ wood particles [20]. Additionally, notable from Table 3 was that the values of $\mu$ and $\mu_{\mathrm{m}}$ decreased at higher $\mathrm{X}$-ray energies (determined at the same $\mathrm{Bi}_{2} \mathrm{O}_{3}$ and wood contents). This could have been due to higher-energy $\mathrm{X}$-rays being less likely to interact with materials through dominant and effective photoelectric absorption, which rapidly decreased with increasing $\mathrm{X}$-ray energies/frequencies, as depicted in Equation (5) [20,46]:

$$
\sigma_{\text {pe }} \propto \frac{\mathrm{Z}^{\mathrm{n}}}{(\mathrm{h} v)^{3}}
$$

where $\sigma_{\text {pe }}$ is the photoelectric cross section, $\mathrm{Z}$ is the atomic number of the element, $\mathrm{h}$ is Planck's constant, and $v$ is the frequency of the X-rays that is directly related to X-ray energy through Equation (6):

$$
\mathrm{E}=\mathrm{h} v
$$

It is also notable that the values of $\mu$ and $\mu_{\mathrm{m}}$ for a neat PVC, calculated using a webbased software (XCOM) [20,47], were similar to WPVC composites without the addition of $\mathrm{Bi}_{2} \mathrm{O}_{3}$, due to the low $\sigma_{\mathrm{pe}}$ of $\mathrm{C}, \mathrm{H}$, and $\mathrm{Cl}$ in $\mathrm{PVC}$, leading to low interaction probabilities between the $\mathrm{X}$-rays and the neat PVC.

The $\mathrm{Pb}$ equivalent thickness $\left(\mathrm{Pb}_{\mathrm{eq}}\right)$, which represents the thickness of material of concern affording the same $\mathrm{X}$-ray attenuation as a $\mathrm{Pb}$ sheet with a certain thickness (under the same specified conditions such as X-ray energies and beam sizes) at 60, 100, and 150-kV X-rays for all WPVC composites are shown in Figure 7. The results revealed that the dependence of $\mathrm{Pb}_{\text {eq }}$ on $\mathrm{Bi}_{2} \mathrm{O}_{3}$ was similar to those of $\mu$ and $\mu_{\mathrm{m}}$ (Table 3) as the $\mathrm{Pb}_{\text {eq }}$ values increased with increasing $\mathrm{Bi}_{2} \mathrm{O}_{3}$ content but decreased with increasing wood content/X-ray energy. For example, the $\mathrm{Pb}_{\text {eq }}$ values of the $10 \mathrm{~mm}$-thick samples were as high as $0.8 \mathrm{~mm} \mathrm{~Pb}$ in those containing $100 \mathrm{pph} \mathrm{Bi}_{2} \mathrm{O}_{3}$, which were considerably greater than for the neat WPVC composites $\left(0 \mathrm{pph} \mathrm{Bi}_{2} \mathrm{O}_{3}\right)$ that only had approximately $0.1 \mathrm{~mm} \mathrm{~Pb}$.

In order to determine recommended $\mathrm{Bi}_{2} \mathrm{O}_{3}$ contents in the WPVC composites for actual use, especially in medical applications, $\mathrm{Pb}_{\mathrm{eq}}$ values obtained from the datasheets of three commercial X-ray shielding products based on a gypsum board (XRoc board) [48], plasterboard (GIB X-Block board) [49] and Knauf Safe board [50], for which the average $\mathrm{Pb}_{\text {eq }}$ values of the commercial products were $0.45,0.70$, and $0.40 \mathrm{~mm} \mathrm{~Pb}$ for the 60,100 , and 150-kV X-rays, respectively, were compared with those from the current work. It should be noted that the $\mathrm{Pb}_{\text {eq }}$ values of the commercial products for $100 \mathrm{kV}$ X-rays were higher than other X-ray energies due to the sharp increase in X-ray interaction probabilities at the K-edge absorption of barium (Ba), which was used as the main X-ray protective filler for the commercial products, that occurs at $37.4 \mathrm{keV}$ [20]. Hence, the $100 \mathrm{kV}$ X-rays, with their average energy around $40-60 \mathrm{keV}$ depending on the type and setup of the X-ray machine, were just above the binding energy of the electron $\mathrm{K}$ shells inside the Ba atoms, leading to immensely enhanced probabilities of X-ray interaction through photoelectric absorption and, subsequently, higher $\mathrm{Pb}_{\text {eq }}$ values at these particular energies [51].

As shown in Figure 7, the $\mathrm{Pb}_{\mathrm{eq}}$ values from the commercial products (represented as red dotted lines) intercepted with the lines of $\mathrm{Pb}_{\mathrm{eq}}$ values from the current work at different $\mathrm{Bi}_{2} \mathrm{O}_{3}$ contents depending on the $\mathrm{X}$-ray energy and wood content. These interception points between the two lines implied the least $\mathrm{Bi}_{2} \mathrm{O}_{3}$ content that could produce the same $\mathrm{X}$-ray attenuation ability as from commercial products, which could be regarded as the recommended $\mathrm{Bi}_{2} \mathrm{O}_{3}$ contents for actual production and use. The results from the determination of the recommended $\mathrm{Bi}_{2} \mathrm{O}_{3}$ contents for all X-ray energies are shown in Table 4, which indicated that the $60 \mathrm{kV}$ and $150 \mathrm{kV}$ X-rays required similar $\mathrm{Bi}_{2} \mathrm{O}_{3}$ contents of 35-40 pph and $40-45 \mathrm{pph}$, while the $100 \mathrm{kV} \mathrm{X}$-rays required the highest $\mathrm{Bi}_{2} \mathrm{O}_{3}$ contents of $85 \mathrm{pph}$ and $100 \mathrm{pph}$, for the WPVC composites containing $20 \mathrm{pph}$ and $40 \mathrm{pph}$ wood particles, respectively. Notably, the recommended $\mathrm{Bi}_{2} \mathrm{O}_{3}$ contents for the $100 \mathrm{kV} \mathrm{X}$-rays were higher than for the other $\mathrm{X}$-ray energies due to the higher $\mathrm{Pb}_{\text {eq }}$ values of the commercial products used as references. Notably, the recommended $\mathrm{Bi}_{2} \mathrm{O}_{3}$ contents for WPVC composites containing 
$40 \mathrm{pph}$ wood particles were higher than those containing $20 \mathrm{pph}$ wood particles due to the suppressed effects of $\mathrm{Bi}_{2} \mathrm{O}_{3}$ particles in attenuating the incident $\mathrm{X}$-rays due to the greater number of wood particles in the composites.
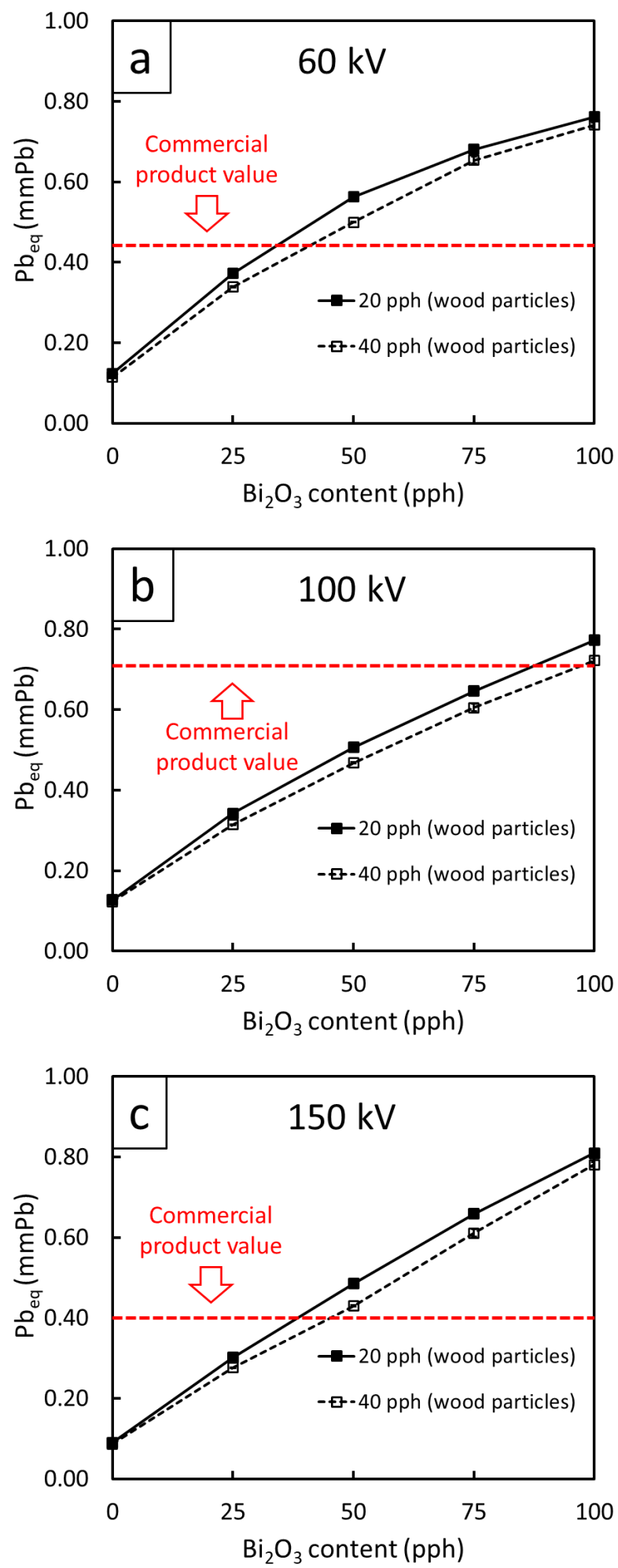

Figure 7. Lead equivalent thickness $\left(\mathrm{Pb}_{\text {eq }}\right)$ of WPVC composites containing 0-100 pph of $\mathrm{Bi}_{2} \mathrm{O}_{3}$ and 20-40 pph of wood particles for X-rays generated from a tube with supplied voltages of (a) $60 \mathrm{kV}$, (b) $100 \mathrm{kV}$, and (c) $150 \mathrm{kV}$. Red dotted lines represent $\mathrm{Pb}_{\mathrm{eq}}$ values of similar commercial X-ray shielding products used for determination of recommended $\mathrm{Bi}_{2} \mathrm{O}_{3}$ contents. 
Table 4. Recommended $\mathrm{Bi}_{2} \mathrm{O}_{3}$ contents in WPVC composites containing $20 \mathrm{pph}$ and $40 \mathrm{pph}$ wood particles for attenuation of X-rays generated from a tube with supplied voltages of 60,100 , and $150 \mathrm{kV}$.

\begin{tabular}{ccc}
\hline \multirow{2}{*}{ X-ray Tube Voltage (kV) } & \multicolumn{2}{c}{ Recommended $\mathbf{B i}_{\mathbf{2}} \mathbf{O}_{3}$ Content (pph) } \\
\cline { 2 - 3 } & $\mathbf{2 0}$ pph Wood & $\mathbf{4 0}$ pph Wood \\
\hline 60 & 35 & 40 \\
100 & 85 & 100 \\
150 & 40 & 45 \\
\hline
\end{tabular}

Lastly, the comparative X-ray shielding properties of the WPVC composites and previously reported composites containing $\mathrm{Bi}_{2} \mathrm{O}_{3}$ with similar filler contents and $\mathrm{X}$-ray energies are shown in Table 5. The results indicated that the WPVC composites in the current work could attenuate $\mathrm{X}$-rays with higher efficiencies than silicone rubber (SR) containing $50 \mathrm{wt} . \%$ of $\mathrm{Bi}_{2} \mathrm{O}_{3}$ but with slightly lower efficiencies than $50 \mathrm{wt} . \%-\mathrm{Bi}_{2} \mathrm{O}_{3} /$ natural rubber latex (NRL) and $35 \mathrm{wt} / \%-\mathrm{Bi}_{2} \mathrm{O}_{3} /$ epoxy composites. The lower $\mu_{\mathrm{m}}$ values in the WPVC composites could have been due to the WPVC composites being investigated at higher X-ray energies as well as having less $\mathrm{Bi}$ atoms dispersed inside the matrix than those in the NRL and epoxy composites, which was possibly caused by fewer filler contents, the type of the main matrix, and the processing method. Nonetheless, despite their lower X-ray shielding properties, the WPVC composites were more rigid and stronger than the NRL and SR composites, making the former suitable in movable partition walls and transportation casks. Furthermore, the WPVC composites also promoted the use of natural products, which can help in reducing agricultural and industrial wastes.

Table 5. Comparative X-ray shielding properties of WPVC and other composites containing $\mathrm{Bi}_{2} \mathrm{O}_{3}$ as X-ray protective filler.

\begin{tabular}{|c|c|c|c|c|}
\hline Matrix & $\mathrm{Bi}_{2} \mathrm{O}_{3}$ Content & X-ray Energy & $\mu_{\mathrm{m}}\left(\mathrm{cm}^{2} / \mathrm{g}\right)$ & Reference \\
\hline WPVC & 100 pph (35 wt.\%) & $100 \mathrm{kV}(\sim 40-60 \mathrm{keV})$ & $0.91-1.01$ & This work \\
\hline Natural rubber latex (NRL) & 100 phr (50 wt.\%) & $80 \mathrm{kV}(\sim 30-50 \mathrm{keV})$ & 1.32 & [12] \\
\hline Silicone rubber (SR) & 50 wt. $\%$ & $55 \mathrm{keV}$ & $1.01-1.20$ & [52] \\
\hline SR & 50 wt. $\%$ & $59 \mathrm{keV}$ & $0.08-0.22$ & {$[53]$} \\
\hline SR & 50 wt. $\%$ & $66 \mathrm{keV}$ & $0.00-0.44$ & [53] \\
\hline Epoxy & 35 wt. $\%$ & $59.54 \mathrm{keV}$ & 1.343 & [54] \\
\hline
\end{tabular}

\section{Conclusions}

This work developed $\mathrm{X}$-ray shielding materials from WPVC composites containing $\mathrm{Bi}_{2} \mathrm{O}_{3}$, with varying contents of wood particles from 20 to $40 \mathrm{pph}$ and of $\mathrm{Bi}_{2} \mathrm{O}_{3}$ from 0 to $100 \mathrm{pph}$ in $25 \mathrm{pph}$ increments. The results suggested that an increased $\mathrm{Bi}_{2} \mathrm{O}_{3}$ content led to non-statistically differences in flexural strength (the values fluctuated in the range 40.92-45.49 MPa), increased X-ray attenuation, Izod impact strength, hardness (Shore D), and density, but decreased water absorption. Furthermore, the results showed that an increased wood content tended to increase the Izod impact strength, hardness (Shore D), and water absorption, but to slightly decrease the X-ray attenuation and density of the WPVC composites. A comparison of the $\mathrm{Pb}_{\mathrm{eq}}$ values obtained from the current work with similar commercial X-ray shielding products for 60, 100, and 150-kV X-rays indicated that the $60 \mathrm{kV}$ and $150 \mathrm{kV} \mathrm{X}$-rays required $\mathrm{Bi}_{2} \mathrm{O}_{3}$ contents of $35-45 \mathrm{pph}$, while the $100 \mathrm{kV}$ $X$-rays required $\mathrm{Bi}_{2} \mathrm{O}_{3}$ contents of 85-100 pph for these WPVC composites to attenuate $\mathrm{X}$-rays with the same levels of efficiency as the referenced products. Lastly, a comparison of X-ray shielding properties between the WPVC composites in the current work and other composites containing $\mathrm{Bi}_{2} \mathrm{O}_{3}$ with similar filler contents and $\mathrm{X}$-ray energies revealed that the former could offer comparable or better $\mathrm{X}$-ray attenuation than the latter for the same range of X-ray energy, indicating that the current work was successful in developing WPVC composites that had both sufficient $\mathrm{X}$-ray shielding and high strength for actual production and use. 
Author Contributions: Conceptualization, E.W., V.R. and K.S.; Formal analysis, W.P., E.W. and K.S.; Funding acquisition, K.S.; Investigation, W.P., E.W. and K.S.; Methodology, W.P., E.W. and K.S.; Supervision, K.S.; Validation, W.P., E.W., T.M., N.S. and K.S.; Visualization, K.S.; Writing-original draft K.S.; Writing-review and editing, W.P., E.W., T.M., N.S. and K.S. All authors have read and agreed to the published version of the manuscript.

Funding: This research was funded by the Kasetsart University Research and Development Institute (KURDI), Bangkok, Thailand, grant number FF(KU)25.64, and the National Research Council of Thailand (NRCT), Thailand.

Institutional Review Board Statement: Not applicable.

Informed Consent Statement: Not applicable.

Data Availability Statement: The data presented in this study are available on request from the corresponding author.

Acknowledgments: Chemicals and materials were supplied by V.P. Wood Co., Ltd. and technical support was provided by the Department of Applied Radiation and Isotopes, Kasetsart University, Bangkok, Thailand, and the Polymer PROcessing and Flow Research Group (P-PROF), King Mongkut's University of Technology Thonburi, Thailand. The Kasetsart University Research and Development Institute (KURDI) and the Specialized Center of Rubber and Polymer Materials in Agriculture and Industry (RPM), Faculty of Science, Kasetsart University, provided publication support.

Conflicts of Interest: The authors declare no conflict of interest. The funders had no role in the design of the study; in the collection, analyses, or interpretation of data; in the writing of the manuscript, or in the decision to publish the results.

\section{References}

1. Li, R.; Lewis, J.H.; Jia, X.; Gu, X.; Folkerts, M.; Men, C.; Song, W.Y.; Jiang, S.B. 3D tumor localization through real-time volumetric $\mathrm{x}$-ray imaging for lung cancer radiotherapy. Med. Phys. 2011, 38, 2783-2794. [CrossRef] [PubMed]

2. $\quad$ Lu, K.; He, C.; Guo, N.; Chan, C.; Ni, K.; Lan, G.; Tang, H.; Pelizzari, C.; Fu, Y.X.; Spiotto, M.T.; et al. Low-dose X-ray radiotherapyradiodynamic therapy via nanoscale metal-organic frameworks enhances checkpoint blockade immunotherapy. Nat. Biomed. Eng. 2018, 2, 600-610. [CrossRef]

3. Rowe, H.; Hughes, N.; Robinson, K. The quantification and application of handheld energy-dispersive x-ray fluorescence (ED-XRF) in mudrock chemostratigraphy and geochemistry. Chem. Geol. 2012, 324-325, 122-131. [CrossRef]

4. Lalhmangaihzuala, S.; Laldinpuii, Z.; Lalmuanpuia, C.; Vanlaldinpuia, K. Glycolysis of poly(ethylene terephthalate) using biomass-waste derived recyclable heterogeneous catalyst. Polymers 2021, 13, 37. [CrossRef]

5. Baron, R.I.; Biliuta, G.; Socoliuc, V.; Coseri, S. Affordable magnetic hydrogels prepared from biocompatible and biodegradable sources. Polymers 2021, 13, 1693. [CrossRef]

6. Forster, B.P.; Till, B.J.; Ghanim, A.M.A.; Huynh, H.O.A.; Burstmayr, H.; Caligari, P.D.S. Accelerated plant breeding. CAB Rev. 2014, 9, 43. [CrossRef]

7. Thomas, G.A.; Symonds, P. Radiation exposure and health effects-Is it time to reassess the real consequences? Clin. Oncol. 2016, 28, 231-236. [CrossRef] [PubMed]

8. Shi, L.; Tashiro, S. Estimation of the effects of medical diagnostic radiation exposure based on DNA damage. J. Radiat. Res. 2018, 59 (Suppl. 2), ii121-ii129. [CrossRef]

9. Bevelacqua, J.J. Practical and effective ALARA. Health Phys. 2010, 98, S39-S47. [CrossRef]

10. Omolola, M.A.; Bidemil, A.; Ademola, J.A.; Olutayo, A.S. Entrance surface dose from pediatric diagnostic X-ray examinations in a developing world setting: Are we 'ALARA principle' compliant? J. Adv. Med. Med. Res. 2013, 3, 2288-2298.

11. Tiamduangtawan, P.; Kamkaew, C.; Kuntonwatchara, S.; Wimolmala, E.; Saenboonruang, K. Comparative mechanical, self-healing, and gamma attenuation properties of PVA hydrogels containing either nano- or micro-sized $\mathrm{Bi}_{2} \mathrm{O}_{3}$ for use as gamma-shielding materials. Radiat. Phys. Chem. 2020, 177, 109164. [CrossRef]

12. Thumwong, A.; Wimolmala, E.; Markpin, T.; Sombatsompop, N.; Saenboonruang, K. Enhanced X-ray shielding properties of NRL gloves with nano- $\mathrm{Bi}_{2} \mathrm{O}_{3}$ and their mechanical properties under aging conditions. Radiat. Phys. Chem. 2021, 186, 109530. [CrossRef]

13. Ninyong, K.; Wimolmala, E.; Sombatsompop, N.; Saenboonruang, K. Properties of natural rubber (NR) and wood/NR composites as gamma shielding materials. IOP Conf. Ser. Mater. Sci. Eng. 2019, 526, 012038. [CrossRef]

14. Reis, L.S.L.S.; Pardo, P.E.; Camargos, A.S.; Oba, E. Mineral element and heavy metal poisoning in animals. J. Med. Med. Sci. 2010, $1,560-579$.

15. Liu, G.; Yu, Y.; Hou, J.; Xue, W.; Liu, X.; Liu, Y.; Wang, W.; Alsaedi, A.; Hayat, T.; Liu, Z. An ecological risk assessment of heavy metal pollution of the agricultural ecosystem near a lead-acid battery factory. Ecol. Indic. 2014, 47, 210-218. [CrossRef]

16. Warniment, C.; Tsang, K.; Galazka, S. Lead poisoning in children. Am. Fam. Physician 2010, 81, 751-757. [PubMed] 
17. Singh, A.K.; Singh, R.K.; Sharma, B.; Tyagi, A.K. Characterization and biocompatibility studies of lead free X-ray shielding polymer composite for healthcare application. Radiat. Phys. Chem. 2017, 138, 9-15. [CrossRef]

18. Chai, H.; Tang, X.; Ni, M.; Chen, F.; Zhang, Y.; Chen, D.; Qiu, Y. Preparation and properties of novel, flexible, lead-free X-ray-shielding materials containing tungsten and bismuth(III) oxide. J. Appl. Polym. Sci. 2016, 133, 43012. [CrossRef]

19. Poltabtim, W.; Wimolmala, E.; Saenboonruang, K. Properties of lead-free gamma-ray shielding materials from metal oxide/EPDM rubber composites. Radiat. Phys. Chem. 2018, 153, 1-9. [CrossRef]

20. Poltabtim, W.; Toyen, D.; Saenboonruang, K. Theoretical determination of high-energy photon attenuation and recommended protective filler contents for flexible and enhanced dimensionally stable wood/NR and NR composites. Polymers 2021, 13, 869. [CrossRef]

21. Sheela, M.; Kamat, V.A.; Kiran, K.; Eshwarappa, K.M. Preparation and characterization of bismuth-filled high-density polyethylene composites for gamma-ray shielding. Radiat. Prot. Environ. 2019, 42, 180-186.

22. Toyen, D.; Saenboonruang, K. Comparative X-ray shielding properties of bismuth oxide/natural rubber composites using a Monte Carlo code of PHITS. IOP Conf. Ser. Mater. Sci. Eng. 2020, 773, 012024. [CrossRef]

23. Toyen, D.; Rittirong, A.; Poltabtim, W.; Saenboonruang, K. Flexible, lead-free, gamma-shielding materials based on natural rubber/metal oxide composites. Iran. Polym. J. 2018, 27, 33-41. [CrossRef]

24. Gwaily, S.E.; Madani, M.; Hassan, H.H. Lead-Natural rubber composites as gamma radiation shields. II: High concentration. Polym. Compos. 2012, 23, 495-499. [CrossRef]

25. Mohan, R. Green bismuth. Nature 2010, 2, 336. [CrossRef]

26. Dong, M.; Xue, X.; Lie, S.; Yang, H.; Li, Z.; Sayyed, M.I.; Agar, O. Using iron concentrate in Liaoning Province, China, to prepare material for X-Ray shielding. J. Clean. Prod. 2019, 210, 653-659. [CrossRef]

27. Li, R.; Gu, Y.; Yang, Z.; Li, M.; Hou, Y.; Zhang, Z. Gamma ray shielding property, shielding mechanism and predicting model of continuous basalt fiber reinforced polymer matrix composite containing functional filler. Mater. Des. 2017, 124, 121-130. [CrossRef]

28. Guermazi, N.; Hadder, N.; Elleuch, K.; Ayedi, H.F. Effect of filler addition and weathering conditions on the performance of PVC $/ \mathrm{CaCO}_{3}$ composites. Polym. Compos. 2016, 37, 2171-2183. [CrossRef]

29. Kajaks, J.; Kalnins, K.; Naburgs, R. Wood plastic composites (WPC) based on high-density polyethylene and birch wood plywood production residues. Int. Wood Prod. J. 2018, 9, 15-21. [CrossRef]

30. Pulngern, T.; Chitsamran, T.; Chucheepsakul, S.; Rosarpitak, V.; Patcharaphun, S.; Sombatsompop, N. Effect of temperature on mechanical properties and creep responses for wood/PVC composites. Constr. Build. Mater. 2016, 111, 191-198. [CrossRef]

31. Srimalanon, P.; Yamsaengsung, W.; Kositchaiyong, A.; Wimolmala, E.; Isarangkura, K.; Sombatsompop, N. Effects of UVaccelerated weathering and natural weathering conditions on anti-fungal efficacy of wood/PVC composites doped with propylene glycol-based HPQM. Express Polym. Lett. 2016, 10, 289-301. [CrossRef]

32. Chen, J.; Teng, Z.; Zhao, Y.; Liu, W. Electromagnetic interference shielding properties of wood-plastic composites filled with graphene decorated carbon fiber. Polym. Compos. 2018, 39, 2110-2116. [CrossRef]

33. Zhang, Y.; Fang, X.; Wen, B. Asymmetric Ni/PVC films for high-performance electromagnetic interference shielding. Chin. J. Polym. Sci. 2015, 33, 899-907. [CrossRef]

34. Yotkaew, P.; Kositchaiyong, A.; Wimolmala, E.; Rosarpitak, V.; Sombatsompop, N. Use of synthetic fibers as co-reinforcing agents in wood/PVC hybrid composites: Effect on tribological properties. J. Reinf. Plast. Compos. 2014, 33, 964-976. [CrossRef]

35. Juntunen, R.P.; Kumar, V.; Weller, J.E.; Bezubic, W.P. Impact strength of high density microcellular poly(vinyl chloride) foams. J. Vinyl Addit. Technol. 2000, 6, 93-99. [CrossRef]

36. The Characteristics, Properties and Uses of Plantation Timbers-Rubberwood and Acacia mangium. Available online: https:/ /www.researchgate.net/publication/237672441_The_characteristics_properties_and_uses_of_plantation_timbers_-_ rubberwood_and_Acacia_mangium (accessed on 2 June 2021).

37. Chan-Hom, T.; Yamsaengsung, W.; Prapagdee, B.; Markpin, T.; Sombatsompop, N. Flame retardancy, antifungal efficacies, and physical-mechanical properties for wood/polymer composites containing zinc borate. Fire Mater. 2017, 41, 675-687. [CrossRef]

38. Terraflex: Hoses and Compound. Available online: https://www.terraflexhoses.com/terra_product/plasticized-compound/ (accessed on 28 June 2021).

39. Lulianelli, G.; Tavares, M.B.; Luetkmeyer, L. Water absorption behavior and impact strength of PVC/wood flour composites. Chem. Chem. Technol. 2010, 4, 225-229. [CrossRef]

40. Zheng, Y.; Zheng, Y.; Ning, R. Effects of nanoparticles $\mathrm{SiO}_{2}$ on the performance of nanocomposites. Mater. Lett. 2003, 57, 2940-2944. [CrossRef]

41. Liu, Q.; Zhou, X.; Fan, X.; Zhu, C.; Yao, X.; Liu, Z. Mechanical and thermal properties of epoxy resin nanocomposites reinforced with graphene oxide. Polym. Plast. Technol. Eng. 2012, 51, 251-256. [CrossRef]

42. Jeamtrakull, S.; Kositchaiyong, A.; Markpin, T.; Rosarpitak, V.; Sombatsompop, N. Effects of wood constituents and content, and glass fiber reinforcement on wear behavior of wood/PVC composites. Compos. B Eng. 2012, 43, 2721-2729. [CrossRef]

43. Lu, H.; Hao, Q.; Chen, D.; Chao, M.; Yao, W.; Zhu, Y. A high-performance $\mathrm{Bi}_{2} \mathrm{O}_{3} / \mathrm{Bi}_{2} \mathrm{SiO}_{5}$ p-n heterojunction photocatalyst induced by phase transition of $\mathrm{Bi}_{2} \mathrm{O}_{3}$. Appl. Catal. B 2018, 237, 59-67. [CrossRef]

44. Nurhazwani, O.; Jawaid, M.; Paridah, M.T.; Juliana, A.H.; Hamid, S.A. Hybrid Particleboard Made from Bamboo (Dendrocalamus asper) Veneer Waste and Rubberwood (Hevea brasilienses). Bioresources 2016, 11, 306-323. [CrossRef] 
45. Berger, M.J.; Hubbell, J.H.; Seltzer, S.M.; Chang, J.; Coursey, J.S.; Sukumar, R.; Zucker, D.S.; Olsen, K. XCOM: Photon Cross Section Database; version 1.5; National Institute of Standards and Technology: Gaithersburg, MD, USA, 2010. Available online: http:/ / physics.nist.gov/xcom (accessed on 3 June 2021).

46. Hashemi, S.A.; Mousavi, S.M.; Faghihi, R.; Arjmand, M.; Rahsepar, M.; Bahrani, S.; Ramakrishna, S.; Lai, C.W. Superior X-ray radiation shielding effectiveness of biocompatible polyaniline reinforced with hybrid graphene oxide-iron tungsten nitride flakes. Polymers 2020, 12, 1407. [CrossRef]

47. Saenboonruang, K.; Poltabtim, W.; Thumwong, A.; Pianpanit, T.; Rattanapongs, C. Rare-earth oxides as alternative high-energy photon protective fillers in HDPE composites: Theoretical aspects. Polymers 2021, 13, 1930. [CrossRef] [PubMed]

48. X-Roc Board, Product Data Sheet. Available online: https://saint-gobain.gr/sites/default/files/xroc_en_0.pdf (accessed on 3 June 2021).

49. GIB X-BLOCK Product Data Sheet. Available online: https://www.usgboral.com/content/dam/USGBoral/Australia/Website/ Documents/English/brochures-catalogues/XBlockRadiationSheildingSystemsApril091.pdf (accessed on 3 June 2021).

50. Knauf Safe Board. Available online: http:/ / www.knauf.com.hk/uploadedFile/20217833961468477067.pdf (accessed on 3 June 2021).

51. Si-Mohamed, S.; Cormode, D.P.; Bar-Ness, D.; Sigovan, M.; Naha, P.C.; Langlois, J.B.; Chalabreysse, L.; Coulon, P.; Blevis, I.; Roessl, E.; et al. Evaluation of spectral photon counting computed tomography K-edge imaging for determination of gold nanoparticle biodistribution in vivo. Nanoscale 2017, 46, 18246-18257. [CrossRef]

52. Jayakumar, S.; Saravanan, T.; Philip, J. Thermal stability and X-ray attenuation studies on $\alpha-\mathrm{Bi}_{2} \mathrm{O}_{3}, \beta-\mathrm{Bi}_{2} \mathrm{O}_{3}$ and $\mathrm{Bi}$ based nanocomposites for radiopaque fabrics. J. Nanosci. Nanotechnol. 2018, 18, 3969-3981. [CrossRef] [PubMed]

53. Jayakumar, J.; Saravanan, T.; Philip, J. Polymer nanocomposites containing $\beta-\mathrm{Bi}_{2} \mathrm{O}_{3}$ and silica nanoparticles: Thermal stability, surface topography and X-ray attenuation properties. J. Appl. Polym. Sci. 2020, 137, 49048. [CrossRef]

54. Muthamma, M.V.; Bubbly, S.G.; Gudennavar, S.B. Attenuation properties of epoxy- $\mathrm{Ta}_{2} \mathrm{O}_{5}$ and epoxy- $\mathrm{Ta}_{2} \mathrm{O}_{5}-\mathrm{Bi}_{2} \mathrm{O}_{3}$ composites at $\gamma$-ray energies 59.54 and $662 \mathrm{keV}$. J. Appl. Polym. Sci. 2020, 137, 49366. [CrossRef] 